\title{
Letter fuels South Africa's AIDS furore
}

Cape Town

International controversy over the South African president Thabo Mbeki's views on the nature of AIDS deepened last week, when the text of an outspoken letter sent earlier this month to US President Bill Clinton, UN secretary-general Kofi Annan and the heads of state of Germany, France and the United Kingdom became public.

In the letter, Mbeki gives the strongest evidence yet of his sympathies for those who argue that AIDS may not be caused by HIV.

Ironically, earlier in the week James Wolfensohn, president of the World Bank, had promised that there would be "no limit" to the funds available for combating AIDS in the developing world. In his statement, delivered during the annual World Bank meeting in Washington, Wolfensohn singled out subSaharan Africa as being in particular need.

The publication of the letter coincided with the release of South Africa's AIDS statistics for 1999, which confirm that nearly ten per cent of its population - about 4.2 million people - is infected with HIV.

Mbeki's letter was passed to The Washington Post by a senior US official, following a meeting in Atlanta the previous week between South Africa's health minister Manto Tshabalala-Msimang, its ambassador to the United States, Makate Sisulu, and Sandra Thurman, director of the White House office of national AIDS policy.

In the letter, Mbeki states that he is "convinced that our urgent task is to respond to the specific threat that faces us as Africans. We will not eschew this obligation in favour of the comfort of the recitation of a catechism that may very well be a correct response to the specific manifestation of AIDS in the West."

Referring to 'dissident' AIDS researchers who believe that HIV does not cause AIDS, he continues: "The scientists we are supposed to put into scientific quarantine include Nobel prizewinners, members of academies of science and emeritus professors of various disciplines of medicine!"

In the South African parliament last Wednesday, Jacob Zuma, deputy president and chairman of the National AIDS Council, denied that Mbeki had at any stage said that he challenges the view that HIV causes AIDS - or the contrary.

"During the last decade and a half and more, a heated debate amongst scientists and others relating to this question, has been going on," said Zuma. Rallying to the president's position, he continued: "We should not, and we will not, leave any stone unturned, even if this means including the views of the so-called 'dissidents.'”

Zuma said that an international panel being set up by the South African government to advise on an appropriate national

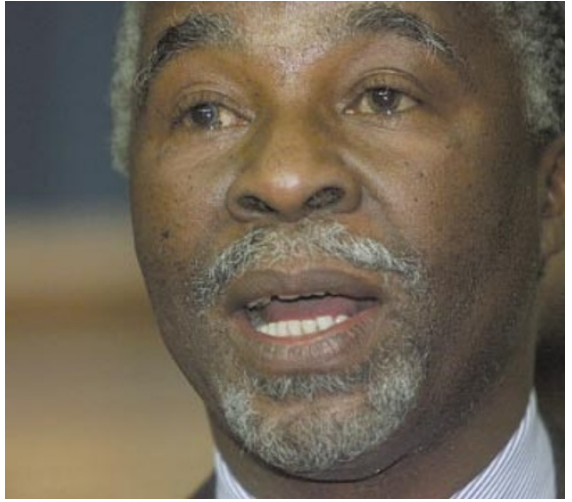

Mbeki: wants to hear views of AIDS ‘dissidents'.

policy on AIDS included "all points of view in the debate and is constituted of the most eminent world scientists who can help to ensure that we understand HIV/AIDS correctly and therefore respond to it correctly".

But the decision to set up the panel, and the way it is being done, has itself come under criticism. Although the panel is due to meet for the first time in South Africa next week, its members have not yet been announced. Two medical researchers, both linked to the dissident movement, are the only people who have confirmed their participation.

One is Gordon Stewart, professor emeritus of public health at the University of Glasgow, who became well known in the 1970s for his opposition to whooping-cough vaccine. The other is Sam Mhlongo, professor of family health at the Medical University of South Africa, north of Pretoria.

In 1997, Stewart co-authored an article with Eleni Papadopulos-Eleopulos of the Royal Perth Hospital, Australia, and other 'dissidents' in the journal Current Medical Research and Opinion. A later article in the same journal by Papadopulos-Eleopulos and others on the pharmacology of AZT, which claimed that the drug was unacceptably toxic, appeared to be a major influence in Mbeki's refusal to sanction state provision of this drug to prevent mother-to-child transmission of HIV (see Nature 402, 3; 1999).

During the debate in parliament last week, Mike Ellis, a member of the Democratic Party, said that Mbeki seemed so defensive about AIDS that he was placing sound judgement and rational thinking at risk. Kobus Gous, health spokesman for the New National Party, accused the president, through his contact with the dissidents, of having "given a podium to discredited scientists, false hope to AIDS sufferers and created doubt in the public mind".

But support for Mbeki's stance came from an unusual quarter when the rightwing Boerestaat Party applauded the president's efforts to "investigate the biggest hoax in the twentieth century". Michael cherry

\section{Unesco backs 'science for debt' plan}

\section{London}

Koïchiro Matsuura, the new director-general of the United Nations Educational, Scientific and Cultural Organization (Unesco), promised this week that his organization will "spare no effort" in backing poor countries prepared to draw up proposals for swapping debt relief for support for science.

Matsuura was speaking at a meeting of African leaders held on Monday (24 April) in Abuja, the capital of Nigeria, to launch an anti-malaria campaign. "Without a scientific capacity of its own, Africa will not be able to tackle and overcome its endemic diseases," he said.

The idea that African countries in particular should develop a strategy under which money earmarked for debt repayments could be channelled into supporting science was endorsed last summer at the World Conference on Science in Budapest, organized jointly by Unesco and the International Council for Science (see Nature 400, 8; 2000).

After the Budapest meeting, Unesco commissioned a report from two former

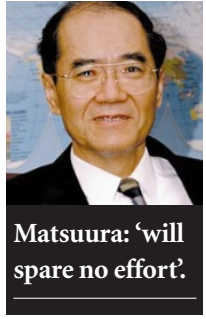

officials of the World Bank on how this could be achieved. The report describes how scientists can integrate their demands into the policy packages put together by their governments under the Heavily Indebted Poor Countries Initiative, a plan drawn up jointly by the World Bank and the International Monetary Fund.

The report says, for example, that it is "essential" to develop an advocacy strategy within a country for supporting science and technology, given that "the bargaining for distribution of resources is an in-country process".

In his speech, Matsuura said the report shows that it is feasible to integrate a science-funding component into negotiations on debt relief, "whatever stage [they] have reached". He added that "debt relief for science should be seized on as an opportunity to strengthen local capacities in basic and applied research". David Dickson 